CASE REPORT

\title{
Homozygous Carrier of Prothrombin G20210A Mutation with Massive Pulmonary Embolism and His Family: Gender Differences of Susceptibility to Mutation
}

\author{
Natalia Y. Stoeva ${ }^{1}$, Vessela S. Koleva² \\ ${ }^{1}$ Pulmonary department, Tokuda Hospital, Sofia, Bulgaria \\ ${ }^{2}$ Clinical laboratory, Tokuda Hospital, Sofia, Bulgaria
}

Correspondence: Natalia Stoeva, Pulmonary department, Tokuda Hospital, Sofia, 51b Nikola Vaptsarov Blvd., 1407 Sofia, Bulgaria E-mail: natalia.stoeva@gmail.com; Tel.: +359884933157

Received: 24 July 2015

Accepted: 20 April 2016

Published: 30 April 2016

Key words: inherited thrombophilias, prothrombin G20210A mutation, venous thromboembolism

Citation: Stoeva NY, Koleva VS. Homozygous carrier of prothrombin G20210A mutation with massive pulmonary embolism and his family: gender differences of susceptibility to mutation.

Folia Medica 2016;58(1);64-66, doi: 10.1515/folmed-2016-0010
Prothrombin $20210 \mathrm{G}>$ A mutation is the second most frequent inherited factor increasing the risk for developing venous thromboembolism (VTE). The risk for VTE in homozygous carriers of this mutation is not well studied because of their rarity are rare. We report a case of a homozygous carrier of prothrombin mutation: a young man with massive pulmonary embolism, and his family - an asymptomatic homozygous sister, heterozygous parents with asymptomatic mother, and father with history of deep venous thrombosis (DVT). To our knowledge, this is the first reported case of homozygous prothrombin mutation carriers in Bulgaria and the other Balkan countries. We conclude that the homozygous prothrombin mutation creates predisposition for VTE that can manifest or not depending on additional factors, one of which could be male gender.

\section{INTRODUCTION}

Prothrombin $20210 \mathrm{G}>\mathrm{A}$ mutation is considered the second most frequent inherited thrombophilia. ${ }^{1}$ The frequency of heterogeneous carriers in general population is $2-5 \%$ and in patients with VTE - 6-18\%. ${ }^{2}$ The latter frequency varies between $5.9 \%$ and $32.1 \%$ in Bulgarian studies. ${ }^{3,4}$ The role of a homozygous carrier of $20210 \mathrm{G}>\mathrm{A}$ mutation as a risk factor for VTE is not well studied because of its rarity. Clinical experience is based on case reports. ${ }^{5,6} \mathrm{~A}$ 2006 review article reported 70 homozygous cases worldwide. ${ }^{7}$ We report a family with two homozygous members. To our knowledge this is the first reported case of homozygous prothrombin mutation carriers in Bulgaria and the other Balkan countries.

\section{CASE REPORT}

A 25-year-old Caucasian man, never smoker, a computer specialist, presented with progressive dyspnea on exertion and at rest, palpitation, right side chest pain, and low grade fever $\left(37.5^{\circ} \mathrm{C}\right)$. The symptoms gradually increased in a week. No external provoking factors were detected; the patient had no history of previous VTE.

Findings: tachypnea (30 per min); oral cyanosis; oxygen saturation - 93\% at room air; slight pleural rubbing in the right bottom chest; heart rate - 115 beats per minute, blood pressure - 100/80.

Laboratory: prothrombin time - $14.3 \mathrm{sec}$ (reference values 10 - $14 \mathrm{sec}) ;$ D-dimer $>35 \mu \mathrm{g} / \mathrm{ml}$. Transthoracic echocardiography: D-shaped left heart chamber with dyskinetic septum; dilated right chamber - $43 \mathrm{~mm}$ with dyskinetic free wall; $1^{\text {st }}$ degree tricuspid valve regurgitation, calculated pulmonary artery systolic pressure - $41 \mathrm{~mm} / \mathrm{Hg}$; TAPSE - $15 \mathrm{~mm}$. Computer tomographic pulmoangiography showed massive bilateral pulmonary embolism with thrombus riding bifurcation of the truncus pulmonalis and occluding a big part of 
the cavities of the main right and left pulmonary arteries and thrombi in all segmental branches bilaterally (Fig. 1).

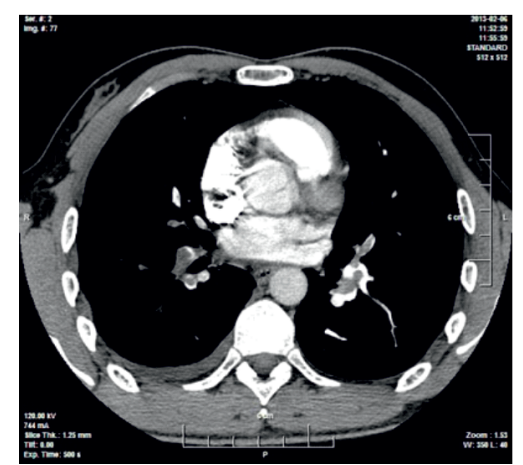

Figure 1. Thrombi in lobar and segmental branches of a. pulmonalis. No peripheral vascularization.

Laboratory examinations for inherited and acquired thrombophilia (thrombophilic examination) found (Fig. 2): homozygous prothrombin 20210AA mutation; heterozygous carrier of PAI-1 4G/5G, A1298C and C677T mutations; absence of Leiden mutation, normal values of antithrombin III (AT III) - $88.5 \%$, protein $C$ (Pr. C) - $114.8 \%$ and protein $S$ (Pr. S) - 130\%. Antiphospholipid antibodies were not found. Homocysteine - $13.03 \mu \mathrm{mol} / \mathrm{l}(\mathrm{N} 0$-15).

We examined the members of his family: both parents and sister. All live together, share the same lifestyle, work at computers and never smoked.

The sister: 24 years old, doesn't take contraceptives, nulligravida, no history of operations, fully asymptomatic. The thrombophilia examination showed her to be a homozygous carrier of prothrombin 20120AA mutation and heterozygous carrier of A1298C and C677T variants of MTHFR gene, normal carrier of PAI-1 5G/5G gene and absence of Leiden mutation (Fig. 2). ATIII, Pr. C and $P r$. $S$ were within normal ranges. Antiphospholipid antibodies were not found. Prothrombin

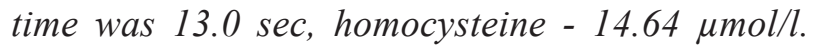

The mother: a 52-year-old woman, multigravida (2 pregnancies) and uneventful hysterectomy at 50. The thrombophilia examination showed her to be a heterozygous carrier of prothrombin G20120 G>A and PAI-1 4G/5G mutations, homozygous carrier of mutant 1298CC and normal of 677CC variants of MTHFR gene, absence of Leiden mutation (Fig. 3). AT III, Pr. C and Pr. S levels were within normal ranges. Antiphospholipid antibodies were negative. Prothrombin time was $13.4 \mathrm{sec}$, homocysteine $10.13 \mu \mathrm{mol} / \mathrm{l}$.

The father: a 51-year-old man with history of unprovoked DVT at the age of 47. He had discontinued treatment with oral anticoagulant 3 years before. No recurrence of VTE. The thrombophilia examination showed him to be a heterozygous carrier of prothrombin G20120A, PAI-1 4G/5G, A1298C and C677T mutations and absence of Leiden mutation (Fig. 3), AT III, Pr. C and Pr. S were in normal ranges. Antiphospholipid antibodies were negative. Prothrombin time was $14.0 \mathrm{sec}$., homocysteine - $17.63 \mu \mathrm{mol} / \mathrm{l}$.

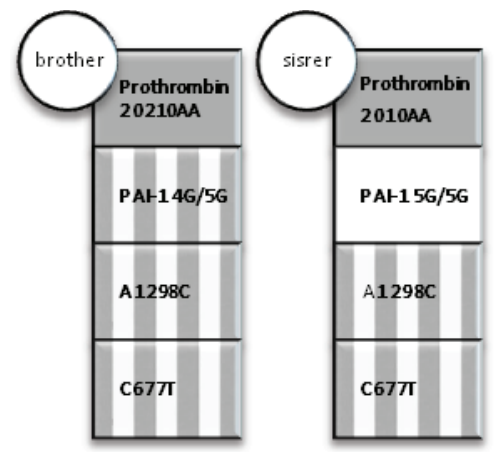

Figure 2. Inherited abnormalities in brother and sister.

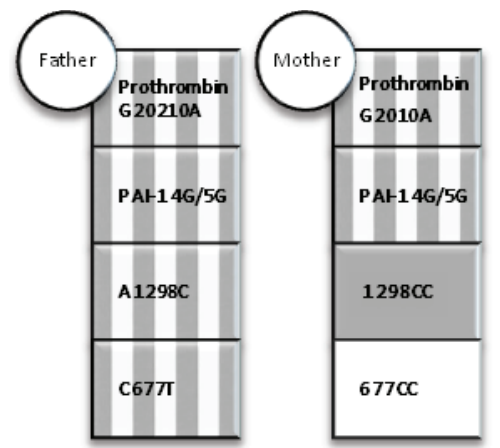

Figure 3. Inherited abnormalities in mother and father.

Legend:

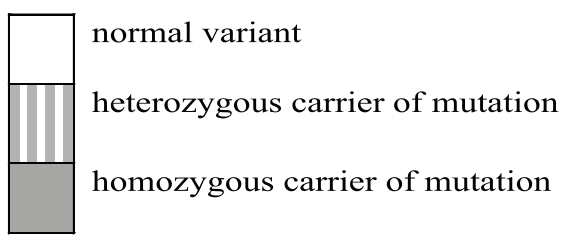

\section{DISCUSSION}

The patient we report is a carrier of several inherited abnormalities. Except for the prothrombin mutation, they are all considered weak thrombophilic factors. That is why we suggest that prothrombin 20210AA mutation in this patient is the leading cause of the massive pulmonary embolism. But his sister is the same age, has similar inherited abnormalities and is 
asymptomatic. Is this by chance or not? The same holds for their parents: the father and the mother are the same age and have similar abnormalities, but only the father had a VTE event, although the mother had precipitating factors such as pregnancies and operation. We hypothesize that the male gender is more susceptible to inherited thrombophilic factors compared to women in equal other circumstances. Our contention is consistent with strong evidence for twice as high risk of recurrence of VTE in men as in women. ${ }^{8}$

\section{CONCLUSION}

The homozygous prothrombin 20210G >A mutation creates predisposition to thrombotic events that can manifest depending on additional factors. We hypothesize that the male gender is one of these factors. Our two cases can be added to the small pool of reported cases of prothrombin 20210AA mutation carriers worldwide.

\section{REFERENCES}

1. Segal JB, Brotman DJ, Necochea AJ, et al. Predictive value of Factor V Leiden and prothrombin G20210A in adults with venous thromboembolism and in family members of those with a mutation. JAMA 2009;301(23):2472-85.

2. Franco RF, Reitsma PH. Genetic risk factors of venous thrombosis. Hum Genet 2001;109:369-384.

3. Ivanov P, Komsa-Penkova R, Kovacheva K, et al. Impact of Thrombophilic Genetic Factors on Pulmonary Embolism: Early Onset and Recurrent Incidences. Lung 2007;186(1):27-36.

4. Elefterova EV. Thrombophilias - clinical, immunological and genetic investigations. http://career. mu-sofia.bg/attachments/article/111/Avtoreferat. pdf.

5. Di Micco P, Di Fiore R, Niglio A, et al. Different outcome of six homozygotes for prothrombin A20210A gene variant. J Transl Med 2008;6(1):36.

6. Roman-Gonzalez A, Cardona H, Cardona-Maya W, et al. The first homozygous family for prothrombin G20210A polymorphism reported in Latin America. Clin Appl Thromb Off J Int Acad Clin Appl Thromb 2009;15(1):113-6.

7. Bosler D, Mattson J, Crisan D. Phenotypic Heterogeneity in Patients with Homozygous Prothrombin 20210AA Genotype. J Mol Diagn 2006;8(4):420-5.

8. Douketis J, Tosetto A, Marcucci M, et al. Risk of recurrence after venous thromboembolism in men and women: patient level meta-analysis. BMJ 2011;342:d813.

\title{
Гомозиготный носитель мутации гена протромбина G20210A с мас- сивной тромбоэмболией легочной артерии и его семья: гендерные различия в восприимчивости к мутации
}

\author{
Наталия Й. Стоева ${ }^{1}$, Весела С. Колева² \\ 1Пульмонологическое отделение, ${ }^{2}$ Клиническая лаборатория, Больница Токуда, София, Болгария
}

Мутация гена протромбина G20210A является вторым наиболее частым наследственным фактором, увеличивающим риск развития венозной тромбоэмболии (ВТЭ). Риск ВТЭ у гомозиготных носителей мутации не очень хорошо изучен из-за их небольшого количества . В данной статье мы сообщаем о случае гомозиготного носителя мутации протромбина - молодой человек с массивной тромбоэмболией легочной артерии и его семья - бессимптомная гомозиготная сестра, гетерозиготные родители с бессимптомной матерью, а отец с историей тромбоза глубоких вен (ТГВ). Насколько нам известно, это первый случай гомозиготных носителей мутации протромбина в Болгарии и других балканских странах. Мы пришли к выводу, что гомозиготная мутация протромбина создает предрасположенность к ВТЭ, которая может проявляться или нет, в зависимости от дополнительных факторов, одним из которых может быть принадлежность к мужскому полу .

Ключевые слова: наследственные тромбофилии, мутация гена протромбина G20210A, венозная тромбо эмболия 